\title{
Between Heavenly and Earthly Liturgy: The Paintings in the Chapel of the Abbey House of Moissac (End of The $12^{\text {Th }}$ Century)
}

\section{Cécile Voyer}

\author{
Université de Poitiers - CESCM
}

e-mail: cecile.voyer@univ-poitiers.fr

\begin{tabular}{l|l|l|l|l|} 
Received: 12 Oct.2015 & Revised: 15 Feb. 2016 & Accepted: 30 March 2016 & Available online: 21 June 2016 & doi: 10.1344/Svmma2016.7.10 \\
\hline
\end{tabular}

\section{Resume}

Dans la chapelle inférieure - construite à la fin du $\mathrm{XI}^{\mathrm{e}}$ siècle - de la tour médiévale, située au nord-est du chevet de l'église abbatiale de Moissac, a été conservé un décor peint d'une grande qualité, datant de la fin du XII ${ }^{e}$ siècle. Il est possible que cet espace ait appartenu à l'hôtel Sainte-Foy, désigné par les textes du XIV siècle comme l'aula de l'abbé. Sur le mur occidental de la chapelle est figuré un arbre de Jessé qui s'étire sur la voûte en berceau plein cintre. Des prophètes, initialement au nombre de douze, complètent l'image centrale. Ils répondaient au collège apostolique associé à la Maiestas Domini, juxtaposée à l'arbre de la lignée christique.

Outre la richesse sémantique de chacune des images, leur association dans l'espace de la chapelle est particulièrement signifiante. Polysémique, le décor évoque non seulement la continuité entre l'Ancien et le Nouveau Testament, mais surtout la réaffirmation de la double nature du Christ dans l'espace liturgique et le sens de l'Église du Christ.

$\mathrm{Au}$ moment de leur réalisation, les peintures de la chapelle ont fait l'objet d'un soin particulier : des inclusions de cabochons en verre ou en métal, des pigments précieux et des apports d'or les enrichissaient, générant des effets sur les spectateurs-acteurs qui se tenaient dans cet espace.

Nous nous intéresserons donc à la signification de ces images, à la mise en scène du sacré dans un lieu de dévotion privée, réservé à l'abbé et aux hôtes de prestige accueillis dans l'abbaye.

Mots clés: Moissac, abbé, arbre de Jessé, Maiestas Domini, liturgie, espace sacré, espace privé de dévotion

\section{Abstract}

A wall-painting programme of great quality dating from the late twelfth century is extant in the late eleventh-century lower chapel of the medieval tower located northeast of the apse of the abbey church of Moissac. It is possible that this area belonged to the hôtel Sainte-Foy, which fourteenth-century texts called the aula of the abbot. On the west wall of the chapel, a Tree of Jesse stretches across the barrel vault. The prophets, originally twelve, complete the central image. They are connected to the Apostolic College associated with the Christ Pantocrator placed next to depiction of Christ's lineage.

Besides the semantic richness of each image, their association in the space of the chapel is particularly significant. The polysemic programme evokes not only the continuity between the Old and New Testaments, but also, especially, the reaffirmation of the dual nature of Christ in the liturgical space and the meaning of the Church of Christ.

Upon their completion, the paintings of the chapel were the subject of particular attention: they were enriched with glass and metal cabochons, precious pigments, and gold, generating effects for the benefit of the viewers-actors who stood in this space.

We will look into both the meaning of these images and the staging of the sacred in a place of private devotion that was reserved for the abbot and the prestigious guests of the abbey.

Key Words: Moissac, abbot, Tree of Jesse, Christ Pantocrator, liturgy, sacred space, private space of devotion 
A sumptuous wall-painting programme dating from the late twelfth century decorated the chapel of the abbey house of Moissac. ${ }^{1}$ Today, only the paintings on the ceiling are partially extant. A Jesse Tree occupies two thirds of the surface of the barrel vault while a Christ Pantocrator covers the last third (Fig. 1).

Building on the comment of Isaiah 11:1, "Et egredietur virga de radice Jesse et flos de radice ejus ascendet," the image of the Tree of Jesse has received significant semantic enrichment based on the wordplay virgo-virga. At Moissac, the prophecy of Isaiah was completed to represent, through the figure of David, the succession of carnal generations up to the Virgin and Christ, who was begotten spiritually. The prophets, like marginal comments, are arranged around the central representation. The Theophany, surrounded by the Tetramorph, is painted on the eastern part of the vault, and the Apostles, associated with the divine manifestation, appear under the arches. The combination of these two themes and the size of the Tree of Jesse on the vault make the decoration of the chapel a singular work. Expression of the nostalgia for the Incarnation and the Epiphany, this programme shows Him who manifested Himself at a specific time and place, and Him who reveals Himself through the ritual. ${ }^{2}$ In other words, it depicts the historical time of the Incarnation and that of the liturgy, which reenacts the Incarnation.

This mural painting was designed to decorate a specific place: a private devotional space. This chapel is located on the lower level of the south tower-largely rebuilt in the eighteenth centuryto the northeast of the apse of the abbey church ("infra septa dicti monasterii versus orientalem partem"). ${ }^{3}$ The tower - the only preserved medieval remnant of the ensemble - belonged to the abbey house, which was subsequently rebuilt first in the second half of the fifteenth century and later in the eighteenth century. The texts from the early fourteenth century mention that in fact this building, described as the hôtel or house of Sainte-Foy, was the aula of the abbot. ${ }^{4}$ It is likely that the hôtel Sainte-Foy already served as abbey house before the fourteenth century but it is difficult to know its first function: was it the lodging of the abbey, designed to accommodate overnight guests, as Chantal Fraïsse suggests? (Fraïsse 2006: 173). The statutes written in 1331 by Auger de Durfort, abbot of Moissac, specify the uses of the place: although some parts were reserved for the abbot, the house was meant to house the sick and to welcome visiting worshipers. ${ }^{5}$

\footnotetext{
${ }^{1}$ It is my pleasure to thank Éric Palazzo for his help, Floréal Daniel and Aurélie Mounier for having trusted me with their work, and Pascal Mora for the beautiful photographs accompanying this article.

${ }^{2}$ See Boureau 1993: 39-54.

${ }^{3}$ On the hôtel Sainte-Foy, see DE LA PeÑa 2001:61 ; 86-87 ; Frä̈sSE 2006: 173-174.

${ }^{4}$ The 1319 sentence specifies: "Aula abbatis Moyssiacensis dicta Sancta Fide” (Arch. nat., JJ 62, f. 3v), cited in DE LA PEÑA 2001: 61

5 "Item, fuit ordinatum quod totum hospitium Sancte Fidis sit infirmorum monachorum et priorum ab extra venientum monasterii supra dicti, excepto quod dominus abbas qui nunc est solum habeat aulam, capellam, cameram cum studio vicinas capelle predicte hospitii supra dicti, cum ipse in persona propria predictas aulam, capellam, cameram et studium voluerit habitare et pro quem quo predicta etiam habitabit, predictis monachis et prioribus predicta competentibus pro tempore pro qua ibidem predictus dominus abbas duxearumdem de jure ad alios pertineret. Qui quidem clerici in monasterii, castrorum et locorum predictorum ecclesiis vel capellis pro eisdem constituentibus et aliis vivis et deffunctis fidelibus missas celebrent omni die aliaque faciant que rationabiliter per constituentes ipsos
} 
Whether it was for the use of the abbot or the distinguished guests, the chapel was probably built in the late eleventh century or shortly before 1100 . The ground level of this space-which is half undergound and has a rectangular plan - is approximately that of the cloister. The place was originally lit by two embrasured bay windows on the south wall and a third one on the east wall. The closure of the axial bay resulted in the opening of a third bay window on the south wall (Fig. 2). A semicircular door, now walled up, allowed access to the chapel from the abbatial apartments to the north. Later on, in the nineteenth century, a modern staircase and a window were added on the west wall of the chapel (Fig. 3).

At the end of the twelfth century during the abbacy of Bertrand (1175-1197) or maybe Robert de Lastide (1198-1205), a painting campaign with significant resources was undertaken to decorate its walls (Fig. 4). Unfortunately, in modern times, the humidity problems and the air currents created by the architectural changes resulted in the alteration of the paintings. The southern part of the decoration of the vault is, to date, incomplete.

The paintings of the abbey house are known since the nineteenth century (LAGRĖZE-FossaT 1870: 110-111). They were the subject of specific studies in the first half of the twentieth century and are mentioned in the great overviews devoted to medieval painting (REY 1945: 116-121; Deschamps, Thibout 1963: 8, 87; Mesuret 1967: 154-155). In his study of the mural paintings of southwestern France, Robert Mesuret links the theme chosen in Moissac with that of the portal of the chapter house of the priory of la Daurade in Toulouse, sculpted around 1180. ${ }^{6}$ However, in our view, although the choice of images shows a shared taste for the typological interpretation of Scripture - which is very common in monastic circles - the themes are not comparable. The portal of the chapter house of the priory was instead inspired by that of the chapter house of the cathedral of Saint-Étienne, made shortly before 1140 by Gilabertus. The column-statues of kings and queens of the Old Testament on the portal of la Daurade were associated with two other images on the jambs: a Madonna and Child and a musician King (David or Solomon). The sculptures that adorned it evoked, through the proclamation of the Incarnation, the historical continuity between the Old and New Testaments. ${ }^{7}$

fuerunt ordinata." Répertoire général des actes, titres, documents des archives du vénérable chapitre de Saint-Pierre de la ville de Moissac, diocèse de Cahors, mis en ordre par Evariste Andurandy, 1730, A.M. Moissac, JJ1, f. 176, no. 1497, cited in DE LA PEÑA 2001: 86-87.

${ }^{6}$ Mesuret 1967: 155: "Le sujet est analogue à celui des sculptures du portail de la salle capitulaire du prieuré de la Daurade qui dépendait de l'abbaye de Moissac. Dépassant l'arbre de Jessé comme le texte du Liber generationis Jesu Christi (Mt. I, 1-16), il donne en raccourci un parallèle des deux testaments où les personnages se répondent ; Jésus à David, les Apôtres aux prophètes. Le sacre du deuxième roi préfigure le second avènement du Fils de l'Homme" [The subject is similar to that of the sculptures of the portal of the chapter house of the priory of la Daurade, which depended on the abbey of Moissac. Going beyond the idea of the Tree of Jesse as the text of the Liber generationis Jesu Christi (Mt. 1: 1-16), it draws an abridged parallel between the two Testaments in which the characters match each other; Jesus matches David, the Apostles match the prophets. The coronation of the second king prefigures the second coming of the Son of Man].

${ }^{7}$ On this topic, see Durliat 1982: 939, and 943. 
Another study on the decoration of the chapel of the abbey house was carried out taking advantage of a restoration campaign conducted in $2001 .{ }^{8}$ Virginie Czerniak, who focused her analysis on the Tree of Jesse, was actually able to identify the extant prophets thanks to the inscription on their scrolls. However, the bulk of her argument was based on the stylistic approach of the paintings (CZERNIAK 2003:75-88). She proposed a date around 1200 and attributed the paintings of Moissac to an English workshop by comparing them with the programme of the chapter house of the Aragonese monastery of Sigena, produced by painters from across the Channel (CZERNIAK 2003: 83-84). Nevertheless, while the overall formal language shows similarities, the two ensembles present important differences. At any rate, this 1200 style is characteristic of a refined taste, suitable for the elites of the time. According to Virginie Czerniak, this singular example, unique in Languedoc, of 1200-style mural paintings might be the mark of the influence of the Plantagenets and the Anglo-Norman culture in Quercy.

Besides the quality of the paintings, already emphasized by all art historians, the richness of the decoration was verified through the physico-chemical analysis of the pigments (MounIER 2010). The presence of gilt and cabochons was observed by Aurélie Monnier, which confirms the importance attributed to the space adorned by these images.

\section{The Tree of Jesse}

A magnificent Tree of Jesse spreads out on a uniform blue background on the western part of the chapel's vault (Fig. 5). ${ }^{9}$ Although it probably took root on the west wall, only the painted figures at the level of the western lunette are extant. The incomplete representation of the prophets located on the west wall makes it possible to think that the tree probably sprouted from Jesse's body, which was painted on the lower register of the wall (Fig. 1).

At the center of the lunette, in a circular space formed by tree branches, King David sits on a throne holding a psaltery. Within his "vegetal mandorla," he plays his instrument while a number of vines fan out to cover the entire wall surface. This thick scrollwork winds onto itself to form spirals that surround large flowers.

A robust trunk that stretches along the axis of the vault emerges strictly aligned with the body of the musician king. The body of Jesse's descendant is associated with the tree structure of the image from end to end, emphasizing the axial dynamic that leads first to the second mandorla, painted in the centre of the vault, and then to the third one crowning its summit, which surrounds Christ as a metaphor for the flower. The Virgin is central because she allows the link between

${ }^{8}$ Conservation and restoration works carried out by Jean-Marc Stouffs in 2001 on the west window, then in 2004 on the vault and finally in 2008 .

${ }^{9}$ Numerous studies have been devoted to the representation of the Tree of Jesse. For a literature review, see LEPAPE 2007. 
Christ, David and the Old Testament. The lineage is clearly represented by the trunk on which the royal ancestor of Christ sits. Thus, the only forebear depicted exalts the royalty of Christ, thus affirming his superiority.

In continuation of the trunk on the vault, another "vegetal mandorla" features the representation of the Virgin, who stands out against a deep blue background (Fig. 5). The upper part of the Marian figure is incomplete. The old descriptions state that the Virgin in Majesty was crowned. This detail-if true - is not insignificant but greatly enriches the meaning of the image. In the centre of the composition, the Virgin is a kind of hinge, a connection point between David and Christ. Although it is still possible to distinguish the shape of the mandorla, the figure of Christ is now lost, like the southern part of the tree. The Holy Spirit as a dove had to accompany the depiction. Fittingly, Anita Guerreau-Jalabert noted that the vertical arrangement of the composition aimed to "oppose Jesse on one end to Christ on the other." The vertical structure imposed by the shape of the tree is, indeed, highly hierarchical: in the upper part of the tree, carnal generation, symbolized by Jesse and David in the lower parts, is replaced by spiritual generation, embodied by the Virgin and Christ, together with the Holy Spirit (GuerReAu-JalaberT 1996:146). The vertical juxtapositions of figures evoke the opposition of the flesh and the spirit but also the domination of the latter over the former.

The meaning of the image is reinforced by its spatial arrangement within the chapel: David, a symbol of Christ's blood kinship, is depicted on the lunette of the west wall, while the Virgin and Christ are painted on the vault. The designer of the programme played on the metaphorical dimension of architecture and the hierarchy of architectural elements: in medieval texts, the vault represents heaven. ${ }^{10}$

For the sake of symmetry, it is indisputable that at least ten prophets framed the line of Christ originally (Fig. 5). On the west wall, two of them were probably represented to either side and slightly at the foot of the vegetal medallion that isolates the majestic figure of David. Due to the opening of a window on the south side of the wall, the only figure still extant today is the one to the north. Two other prophets probably flanked Jesse in the lower part of the west wall. In contrast, four prophets are extant on the vault.

Although the designer of the programme individualized each prophet, he also sought to mark their connection with the Hebrew era through phylacteries - an attribute of the characters of the Old Testament—-long hair for most of them, and a beard for the patriarchs (Fig. 6).

In accordance with the recurring representation of the Tree of Jesse, prophets occupy a lateral position (GUERREAU-JALABERT 1996: 146). They are actually sitting on the scrollwork that spreads

${ }^{10}$ On this vast topic, see Mortet, Deschamps 1911-1929; CAhn 1976: 247-254; Whitehead 2003. 
across the entire vault. The painter stressed the exteriority of the figures of the Old Testament in relation to the tree with some details like the phylacteries that overlap the vegetal maze and do not follow the serpentine undulations of the vines. Slightly rigid, the scrolls are used to define a space that features incriptions with the names of the prophets. Thus, we can distinguish AGHEVS (Haggai) next to David, and also [J]ONAS (Jonas) [M]ICHEAS (Micah), NAVM (Nahum), and ABACVS (Habakkuk). The scrolls that allow the introduction of their names in the visual field provide the inscriptions with motion and direction. Here the names of those who were appointed by God to prophesy rise and ascend to heaven.

If the prophets were to be represented by an ensemble of twelve, chosing a coherent group seems logical: the Minor Prophets. ${ }^{11}$ In Book XVIII of the City of God, Augustine developed an essentially Christological and ecclesiological interpretation of the message of each of the twelve minor prophets. According to Augustine, Hosea evokes the mystery of Christ, the King, the true David: that is, the mystery of the resurrection. The announcement of the advent of the Church by Joel is resumed by the Apostles themselves (Acts 2: 17-18). Amos is presented as the prophet of Christ and the Church. Obadiah announced that the Saviour would come to Mount Zion and that the apostles represented those that were "saved" on the mountain. Christ's disciples have brought the nations into the kingdom of the Lord. The death, resurrection and ascension of Christ are at the heart of the prophecy of Jonah. Micah pictured Christ under the sign of a high mountain and announced his birthplace. Nahum predicted the descent of the Holy Spirit upon the apostles. Habakkuk prophesied the coming of Christ. Zephaniah evoked redemption through the remains of Israel; as for Haggai, he proclaimed the upheaval of the world after the Incarnation (LA BonNARDIÈRE 1963: 343).

The choice of essentially depicting the prophets and not the kings of Judah is interesting. Of course, as Hélène Toubert pointed out, the aim is always marking the continuity between the Old and New Testaments:

la tige de l'Ancien Testament est aussi vigoureuse que celle qui lui succède. Tout autant que le renouvellement intervenu par l'Incarnation, la continuité de l'un à l'autre est visible et affirme la présence de l'Ancien Testament dans le patrimoine chrétien. [The stalk of the Old Testament is just as strong as the one succeeding it. The continuity from one Testament to the other is just as visible as the renewal brought about by the Incarnation, and affirms the presence of the Old Testament in the Christian legacy] (TOUBERT 1990: 85-86)

However, the addition these twelve prophets on the margins of the tree reinforces the themes of the begetting and redemption intrinsic to the main representation. Moreover, these particular

\footnotetext{
${ }^{11}$ In the eleventh century, the library of the abbey of Moissac had three manuscripts of Augustine's work (one of the two extant catalogues of the eleventh-century library lists the Libri conditi in teca librorum cenobii Moissiacensis, BnF, lat. 4871 (86), f. 160v). See the works in Dufour 1981: 175-226; 1982a: 147-173; 1982b: 115-138. The copies of at least twenty-five Augustinian texts are documented at the end of the twelfth century. On this topic, see FraïsSE 2006: 200 .
} 
prophets clearly introduce an ecclesial theme. The Incarnation of Christ and the meaning of his Church are evidenced by the historical continuity between the Old and the New Testament.

The vegetal abundance of the Tree of Jesse is such that the term 'exuberance' can be applied to Moissac (CZERniak 2003: 82). The concern with the ornamentation, the taste for the foliage and the flowers in full bloom flowers are of course to be considered but the explanation is, in our view, insufficient. We agree with the assumptions of Anita Guerreau, who showed that the lushness of the tree in the representations of the "virga Jesse" is opposed to "the lateral nature, the often sickly appearance, and even the lack of vegetal motifs in the early examples of family "trees" (GuerReau-JalaberT 1996: 154) The difference between the "virga" of prophecy and the sturdy trunk with abundant foliage painted in the chapel is therefore important. More consistent with the words of Isaiah, the oldest images of the Tree of Jesse did not feature this flourishing vegetation either. Thus, in the lower register of the facade of Notre-Dame-la-Grande in Poitiers (1115-1130), the stem, extended with some branches, which emerges from Jesse's head, is topped with a flower and a bird (Fig. 7). Therefore the vegetal and ornamental proliferation should be considered as potentially significant.

The spiritual value of the tree has been addressed by a number of researchers. ${ }^{12}$ This plant is associated with the idea of salvation and rebirth. Alive and fertile, it is the image of the tree of life, and also an allegory of 'Ecclesia' (Palazzo 1992: 102-120; Paris-Poulain 1997: 121-137; GuerReAu-JALABERT 1996: 154-155). The one that grows on the ceiling of the chapel of the abbey house with its abundance of flowers, and dense foliage is a lively and prolific tree. Not without reason, Anita Guerreau hypothesized that a medieval cleric would see in these flourishing trees, carrying the finest fruit, "the tree of life, of Christ, the Cross and the 'Ecclesia', that of spiritual life and salvation" (GUERREAU-JALABERT 1996: 155).

The plastic quality of the tree structure is undeniable: the most impressive flowers are concentrated around the figure of the Virgin and Christ. Their size decreases towards the periphery where the prophets are depicted. Floral scrolls invade and fill the space available on either side of the trunk. This ornamental brilliance not only imparts motion, rhythm, and punctuation to the whole representation but also, and above all, provides the plant metaphor-the fruitful tree - with an additional semantic power. ${ }^{13}$ The blooming foliage around the tree and its inhabitants is not only a way of signifying the mystery of the divine plan, but also its ornamental beauty, "its aesthetic evidence," the "invisible virtus" of the sacred (BonNe 1997: 118).

\footnotetext{
${ }^{12}$ The bibliography on the theme of the tree is very rich, see Toubert 1990: 37-63; 65-89. The Church was frequently identified with the tree in the Office of Dedication, the passage in Luke 19: 1-10 lent itself to various commentaries around this theme. For textual references, see GoETz 1965.

${ }^{13}$ On 'ornamentality' and its most significant principles, see BonNe 1997: 103-119. We agree with his definition: "Entre représentationnel et ornemental, la différence n'est pas ici l'objet mais le registre fonctionnel au sein du même objet. L'ornemental relève de la rhétorique de l'énonciation plutôt que de l'énoncé" [Between representational and ornamental, the difference is not the object but the functional register within the object itself. The ornamental nature relies on the rhetoric of the enunciation rather than on what it enunciates] (BonNE 1997: 112).
} 
In the lower register, David is the only representative of Christ's royal bloodline. The Virgin is the hinge point between carnal and spiritual/divine kinship. The image evokes, through the nature of the conception itself, the dual nature of Christ. A valued figure, the Virgin occupies the centre of the composition and is set against a deep blue background. The sacredness of the image is expressed not only by its location within the space of the chapel, but also through the pigments that were used to produce it. Whereas the light blue that forms the background for the entire image was obtained using aerinite, ${ }^{14}$ the "back-wall" against which the Marian figure is placed was painted with lapis lazuli. The preciousness of the pigment obviously acts as a hierarchical marker in the programme, but it also serves to express the sponsors' devotion to the Virgin.

The primary role of Mary is emphasized by certain prophets that refer to her. As the vehicle of the Incarnation, she is the place of fulfillment of the promises made to Israel. Moreover, the pictures of the first half of the twentieth century suggest that the Virgin was crowned. ${ }^{15}$ This significant detail, which would grant her the title of Queen of Heaven, makes her the Bride and incarnation of the Church. Thus, in the Tree of Jesse, the Virgin occupies a pivotal position where the passage from carnal generation to spiritual kinship comes to be. But here she is also the personification of the Church whose sacramental role is to operate the daily transformatio / transmutatio. As Anita Guerreau recalled, besides the Eucharistic transmutatio, baptism is also part of this turnaround process (Guerreau-JaLABERT 1996: 156). The Tree of Jesse is the defining image of the meaning of the Church of Christ: it expresses not only the transition from the time "sub lege" to the "sub gratia" period, but also the exact time of the transmutation from the carnal to the spiritual through the Marian and ecclesial figures. Thus, it evokes the work of redemption towards which the Church works daily.

With good reason, Anita Guerreau has also noted that "the Virgin's position (in the tree) is homologous with that of the Church in the ritual system and the structure of society, where it appears as a forced intermediary between men and God" (GuerREAU-JALABERT 1996: 162). The hierarchical organization of figures in accordance with the verticality of the tree asserts the domination of the spiritual over the carnal. Therefore, according to the hypothesis of Anita Guerreau, with which we agree, it reinforces the domination of the Church, the earthly agent of the transformatio and the commutatio (Rosé 2011: 113-138), the only one capable of engendering spiritual life through the sacraments and of transforming material goods into spiritual goods.

\footnotetext{
${ }^{14}$ The pigment comes from Catalan (Lleida) and Aragonese (Huesca) aerinite deposits. Deposits of this clayey mineral exist in Navarre and Andalusia (Malaga). One deposit was discovered in France in Saint-Pandelon near Dax. Its use seems quite rare in French Romanesque mural paintings and coincides with the geographical area south of the Pyrenees. On this topic, see DANiEL et al. 2008.

${ }^{15}$ It seems that the crown was still visible in the 1960s. Robert Mesuret wrote: "Le décor de rinceaux dont les volutes portent des fleurons se continue sur la voûte du berceau pour former au centre une sorte de mandorle où une femme est assise et couronnée" [The decoration of foliage scrolls featuring fleurons continues on the barrel vault to form in the centre a kind of mandorla where a crowned woman sits] (MESURET 1967: 155).
} 
Another detail merits special attention: the author of the Psalms, who reformulated the word of God, is playing a psaltery amidst a profusion of plants. Whereas the lushness evokes fertility, in the Psalm's exegesis the plant — bearer of an important symbolism — is often likened to the Word and its dissemination in the world through the Spirit (MARCHESIN 2000: 117-118). The coils of the foliage may be the visual translation of music - the word of God - produced by the king, foreshadowing the Incarnate Word. Just as the ordainment of the created world relies on music, based on numbers and measurements, the Tree of Jesse is part of the perfection of the divine plan. The incarnation indeed opened the path of salvation to men.

\section{Christ Pantocrator and the Apostles}

The second extant figure depicts the Divine Majesty surrounded by the Tetramorph and framed by the apostles (Fig. 1). This image, oriented towards the Tree of Jesse but set apart by a large band of acanthus leaves and bordered with red-edged ocher-coloured ribbons, occupies a third of the vault. The band marks a true boundary between the two representations, which confront two images of God incarnate.

The Christ Pantocrator is depicted on the eastern part of the vault, above the spot where the original altar of the chapel was most likely placed (Fig. 8). Thus, it materialized the presence of God during the Eucharistic sacrifice; a presence explicitly proclaimed in the preface to the Canon of the Mass (SkUBISZEwski 2005: 309-408). The Four Living Creatures are associated with the Theophany: polysemic figures if there ever were any, they are at the same time the creatures in Ezekiel's vision (Ez 10: 14), those in the vision of John (Rev 4: 6-8) and also, according to the exegetical tradition, the sign of the evangelists, each of them embodiment of an "essential dogmatic aspect": humanity, royalty, sacrifice, and resurrection. ${ }^{16}$ From Irenaeus of Lyon onwards, biblical exegesis progressively established a correspondence between the cherubs in Ezekiel's vision, the Four Living Creatures, the evangelists, and the basis for the divinity of Christ. These figures are an expression of the uniqueness of the Logos but also, borrowing from Piotr Skubiszewski, the images of its activity, "its operation modes."17

\footnotetext{
${ }^{16}$ Irenaeus of Lyon wrote: "Ensuite, pour nous, il se fit homme ; enfin, il envoya le don de l'Esprit céleste sur toute la terre, nous abritant ainsi sous ses propres ailes. En somme, telle se présente l'activité du Fils de Dieu, telle aussi la forme des vivants, et telle la forme de ces vivants, tel aussi le caractère de l'Évangile, quadruple forme de l'activité du Seigneur" [Then, for us, he became man; finally, he sent the gift of the heavenly Spirit over the earth, thus sheltering us under his wings. In sum, thus the activity of the Son of God presents itself, such as well is the shape of the four living creatures, and such is the form of these living creatures, such as well is the character of the Gospel, the quadruple form of the activity of the Lord], Contre les Hérésies. Livre III, Rousseau, Doutreleau (eds.) 1974: 160-171 (III, 11, 8), cited in SkUVISZEwSKr 2005: 315. Jerome later fixed the correspondence disseminated by medieval exegesis: the power of these beings was transferred to the evangelists, which then symbolized four attributes of Christ: the lion / Mark-his kingship, the bull / Luke-his priesthood, the man / Matthew-his humanity, and the eagle / John-his divinity.

${ }^{17}$ SKUVISZEWSKI 2005: 316 . In the exegetical tradition, the quaternity, an immanent category in the Theophany, is the expression and the sign of the divinity of Christ.
} 
The Christ Pantocrator adored by the Tetramorph occupies a place - a rectangular space - of its own, defined by a blue border, accented with cabochons (Fig. 9). The sacredness of this space was enhanced by the materiality of the visual work, which concentrated the most expensive pigments, cinnabar and lapis lazuli. The sense of wonder intrinsic to the Theophany was accentuated by tin-foil gilded halos and, in all likelihodd, the presence of glass paste and metal cabochons. ${ }^{18}$ The glow of the candles during the ritual had to make the the vision of God above the altar scintillate. Thus, the "in presentia" of the divine in the material world was activated by the image during the liturgical mise en scène. ${ }^{19}$

This area of the chapel is the place of mystery, an expression of the sacred and divine. This representation is at once the sign of the Incarnation and the Revelation. Equivalent to an apsidal theophany in this space, the divine manifestation is not completed by the figure of angelic creatures, seraphs or angels, but by the apostles that frame the theophany (Fig. 8). However, the apostles belong to a different place and space different from that reserved for God. On the margins of the theophanic vision, the apostles - originally twelve in number, of which only six are still visible today-are represented enthroned under semicircular arches. They attend the divine manifestation as spectators: the architectural configuration and the structure of the image place them in the position of observers of the mystery. The presence of Christ's disciples grants the composition an ecclesial dimension; an evocation of the early Church, it is also the image of the universal Roman Church. Besides the permanence of the divine kingdom and the universal Church, the apostolic college also evokes the Last Supper, the founding act of the Church on earth. This image is the projection of what takes place daily on the altar when the priest repeats the gestures of Christ instituting the Eucharist during the last Passover. Similarly, the transubstantiation of species reproduces the mystery of the incarnation every day. Thus, the Church of Christ, founded by the apostles in the image of their heavenly ideal, participates in the economy of salvation by arranging the Incarnation and the Redemption.

Whereas the presence of the apostolic college proclaims the divine ancestry of the Church, its symbolic location on both sides of the altar — the connection point between heaven and earth - is particularly significant. The earthly Church continues, through its representatives, the mission of the apostles. Through their sacramental role, priests, the vicars of Christ, perform the daily transmutatio and commutatio from the material to the spiritual. According to Amalarius of Metz, whose influence on medieval Eucharistic theology was predominant, the priest performs ritually what Christ performed corporeally on earth. ${ }^{20}$

\footnotetext{
${ }^{18}$ This "false gilding" is made of metal sheets covered with yellow paint, see MounIER 2010: $198 ; 395$.

${ }^{19}$ On the concept of in presentia, see Hameline 1997: 109-112; Palazzo 2012: 42.

${ }^{20}$ Amalaire de Metz, Missae expositionis geminus codex. Codex expositionis. Codex seu scedula prior 1, vol. 1: 263.
} 
The two images evoke and affirm the dual nature of Christ through the lineage of David, and the expression of Christ's majesty. Thus, both the Tree of Jesse and the Pantocrator express the dual nature of God incarnate. Piotr Skubiszewski and Herbert Kessler noted in their works that the need to emphasize at the same time the human and divine nature of Christ was constant during the Middle Ages (Skubiszewski 2005: 376 ; Kessler 2007). The Christ Pantocrator is probably the most complete visual representation of the definition of Christ as God and man. The northern tympanum of San Miguel de Estella, in Navarre, from the late twelfth century, exemplifies it. On the quatrefoil mandorla circumscribing the body of the Logos, we find the inscription: "Nec Deus est nec homo presens quam cernis imago/ Sed Deus est et homo quem sacra figurat imago."21 Adored by the Four Living Creatures, Christ is surrounded by John and Mary, mirroring the sacrifice of Calvary, an expression of the dual nature of Christ. Pictured in his full physicality, he holds a book whose binding is decorated with the Christogram. The Book, a sign of the Word, another kind of incarnation of the Logos, is associated with the absolute sign of Christ the Lord: the Chi / Rho - referring to the Crucifixion — and the Alpha and the Omega - an evocation of the Parousia.

The Tree of Jesse represents the essence of the Incarnation, the transition from the carnal to the spiritual and the begetting of the Spirit. From the Patristic period onwards, Eucharistic theology considered the transformation of species as a reiteration of the Incarnation. ${ }^{22}$ The human ancestry of Christ is signified through the mention of David. Ignatius of Antioch (98-117), for example, identified the bread and wine with the historical Christ, born of the seed of David through the Incarnation. ${ }^{23}$ In the twelfth century, the school of Laon, under the leadership of William of Champeaux (1113-1121) insisted, following Anselm (ca 1109-1117), on the presence of Christ as a whole — body, soul and divinity — in each species. ${ }^{24}$ In other words, each of the two images of the chapel asserts the dual nature of Christ. The sacramental body is indeed regarded as the historical body of Christ, whose most accomplished evocation is the Tree of Jesse. The Christ Pantocrator embodies the divine presence during the Mass, when the verum corpus is placed on the altar. The subtle combination of the two images on the ceiling of the chapel recalls the Incarnation, which ended the Mosaic era; the preeminence of the spiritual over the carnal and the daily repetition of the Incarnation through the sacramental transformation of the species.

\footnotetext{
21 "This image you see is neither God nor man / But he is God and man, Him who appears in this sacred image." Example cited in Skubiszewsis 2005: 376, Kessler 2007: 72-73. See also, Favreau 1975: 237-246. On this text, written by Baldric of Dol, see BUDDE 1975: 127-139, especially 133-136.

${ }^{22}$ On this topic, see Mazza 1999. Paschal Radbert wrote: "si carmen illam vere credis de Maria virgine in utero sine semine potestate Spiritus Sancti creatam, ut Verbum caro fieret, vere crede et hoc quod conficitur in verbo Christi per Spiritum Sanctum corpus ipsius esse ex virgine," (De corpore et sanguine Domini 4 ; CCCM 16: 30).

${ }^{23}$ Ignatius of Antioch explains: "It is the bread of God I want, which is the flesh of Jesus Christ, of the seed of David, and for drinking I want his blood, which is incorruptible love" (Letter to the Romans 7, 3, SC 10, p. 117).

${ }^{24}$ On this topic, see MACY 1984: 75.
} 
Signs of the divine in the sensible world, these two images demonstrate the different ways of visualizing the Word throughout history and at the precise moment of the ritual. They thus mark a progression in the space of the chapel: from the Incarnation announced to the Incarnation accomplished and repeated. Thus, these two representations evoke the historical and liturgical times, which merge at the moment of the ritual performed on the altar. Only the priests, the true commutati, in their position of mediators between God and men, have the power to renew the Incarnation. Through community liturgy, the monks, members of the fraternitas and spiritual sons of the Virgin-Church, partake of the Incarnate. The redemption process is carried out through the sacrifice of the body of the Word for the ritual in which the Eucharistic transformation takes place. The purity of monastic life grants these privileged religious men the daily contemplation of the divine and gives them a key role in the economy of salvation.

The Incarnation is at the heart of the visual thought that led to the design of this programme and its defining point, the daily renewal operated by the Church. ${ }^{25}$ The apostles gathered around the Christ Pantocrator are the image of the primitive Church, a metaphor for the unity of the Roman and universal Church. The ecclesial sense of the decoration is enhanced by the presence of the twelve Minor Prophets. Returning to the metaphor of the tree, did Rupert of Deutz not write: "the Incarnation of Christ is the root of the Holy Church"? ${ }^{26}$

The two images on the vault seem to highlight the mediating role of the Church, which, through its priests, is the operator of both the transformatio and the commutatio on earth. Mater Ecclesia is indeed the place of such transformation, at the heart of tree structure painted on the vault. It is the place of mystery body of the Word becomes flesh; the place of mystery where the sacramental and the historical bodies of Christ become one; it is the place of redemption where caritas brings together the Word and men.

Although the altar has several meanings depending on the different parts of the ritual, all reflect a close relationship between the Eucharist and the work of salvation accomplished by Christ. Thus, the two main images of the chapel offer a full reading of the history of salvation through the Incarnation and the sacrifice. They show at the same time they affirm.

Thus, the sparkling and scintillating decoration of the abbot's chapel aimed to surround those inside it with the absolute beauty of the mystery that took place there every day.

\footnotetext{
${ }^{25}$ The presence of the apostles on either side of the Christ Pantocrator allows the ecclesial interpretation of the image.
}

${ }^{26}$ Rupert de Deutz, PL. 168, col. 1092, cited in Toubert 1990: 83. 


\section{BIBLIOGRAPHY}

Bonne, Jean-Claude, 1997. "De l'ornement à l'ornementalité. La mosaïque absidiale de San Clemente de Rome", Le rôle de l'ornement dans la peinture murale du Moyen Âge, Actes du

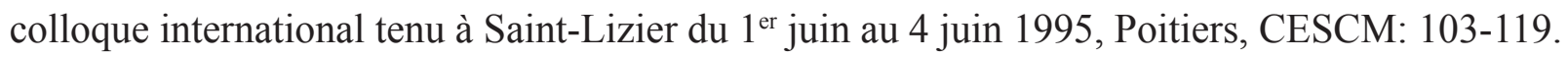

Boureau, Alain, 1993. "La mise en scène du divin", L'événement sans fin. Récit et christianisme au Moyen Âge, Paris, Les Belles Lettres

BudDE, Rainer, 1975. "Effigiem Christi, qui transis, semper honora. Verses condemning the cult of sacred images in art and literature", Acta ad archaeologiam et Artium Historiam Pertinentia, 11: $127-139$

CAHN, Walter, 1976. "Architectural Draftsmanship in Twelfth-Century Paris: The Illustrations of Richard of Saint-Victor's Commentary on Ezekiel's Temple Vision", Essays in Honor of Sumner McKnight Crosby, Gesta, 15, 1/2: 247-254

Czerniak, Virginie, 2003. "Les peintures murales de la chapelle de l'ancien logis abbatial de Moissac. Un exemple méridional de l'influence des Plantagenêt", Mémoires de la société archéologique du Midi de la France, LXIII:75-88

Daniel, Floréal, Laborde, Barbara, Mounier, Aurélie, Coulon, Émilie, 2008. "Le pigment d'aérinite dans deux peintures murales du Sud-Ouest de la France", ArchéoSciences [en ligne], 32, http://archeosciences.revues.org/987, [2011/10/01]

De La Peña, Nicole, 2001. Les moines de l'abbaye de Moissac de 1295 à 1334, Turnhout, Brepols

Deschamps, Paul, Thibout, Marc, 1963. La peinture murale en France au début de la période gothique, Paris, Centre national de la Recherche scientifique

Dufour, Jean, 1972. La bibliothèque et le scriptorium de Moissac, Genève-Paris, Droz -1981. "La composition de la bibliothèque de Moissac à la lumière d'un inventaire du XVII siècle nouvellement découvert", Scriptorium, 35: 175-226

-1982a. "Manuscrits de Moissac antérieurs au milieu du XII e siècle nouvellement identifiés: description codicologique et paléographique", Scriptorium, 36: 147-173

-1982b. "Les manuscrits liturgiques de Moissac", Liturgie et Musique (IXe-XIVe siècle), Cahiers de Fanjeaux, 17: 115-138 
Durliat, Marcel, 1982. "La dernière sculpture romane”, La France de Philippe Auguste, le temps des mutations, colloque international du CNRS n 602, Paris, CNRS : 939-953

Favreau, Robert, 1975. "L'inscription du tympan de San Miguel d'Estella", Bibliothèque de l'Ecole nationale des Chartes, 133: 237-246

Fraïsse, Chantal, 2006. Moissac, histoire d'une abbaye, Mille ans de vie bénédictine, Cahors, La Louve éditions

Goetz, Oswald, 1965. Der Feigenbaum in der religiösen Kunst des Abendlandes, Berlin, Mann

Guerreau-Jalabert, Anita, 1996. “L'arbre de Jessé et l'ordre chrétien de la parenté”, dans Marie, le culte de la Vierge dans la société médiévale, D. Iogna-Prat, É. Palazzo, D. Russo (eds.), Paris, Beauchesnes:137-170

Hameline, Jean-Yves, 1997. La poétique du rituel, Paris, Cerf

Kessler, Herbert L., 2007. Neither God or Man. Words, Images and Medieval Anxiety about Art, Berlin, Rombach Verlag

La Bonnardière, Anne-Marie, 1963. "Les douze petits prophètes dans l'œuvre de saint Augustin”, Ancien Testament, Biblia Augustiniana, 24: 341- 374

Lagrèze-Fossat, Adrien, 1870. Études historiques sur Moissac, t. III, Paris, Dumoulin

LEPAPE, Séverine, 2007. Étude iconographique de l'arbre de Jessé en France du Nord du XIV siècle au XVII siècle, thèse de $3^{\mathrm{e}}$ cycle (dactyl.), J.-Cl. Schmitt (dir.), EHESS

Macy, Gary, 1984. The Theologies of Eucharist in the Early Scholastic Period. A Study of the Salvific Function of the Sacrament according to the Theologians c. $1080-$ c. 1220, Oxford, Clarendon Press.

MARCHESIn, Isabelle, 2000. L'image organum, La représentation de la musique dans les psautiers médiévaux, 800-1200, Turnhout, Brepols

Mazza, Enrico, 1999. L'action eucharistique, Origine, développement, interprétation, trad. de l'italien par J. Mignon, Paris, Cerf 
Mesuret, Robert, 1967. Les peintures murales du Sud-Ouest de la France du XI au XVI' siècle, Paris, éditions A. et J. Picard

Mortet, Victor, Deschamps, Paul, 1911-1929. Recueil de textes relatifs à l'histoire de l'architecture et à la condition des architectes en France, au Moyen Âge (XI ${ }^{e}$-XIII' siècles), 2 vol., Paris, Picard

Mounier, Aurélie, 2010. Aurum, argentum et aliae res innumerabiles, Les dorures dans les peintures murales médiévales du Sud-Ouest de la France, Thèse de $3^{\mathrm{e}}$ cycle en archéométrie, F. Daniel (dir.), Bordeaux 3

PALAzzo, Éric, 1992. "Iconographie et liturgie : les mosaïques du baptistère de Kélibia (Tunisie)", Archiv für Liturgiewissenschaft, 34: 102-120

-2012. “Art, Liturgy and the Five Senses in the Early Middle Ages”, Viator 41, 1: 25-56

Paris-Poulain, Dominique, 1997. "Une représentation de l'Arbor-Ecclesia : contribution à l'étude des peintures murales du Petit-Quevelly", Le rôle de l'ornement dans la peinture murale du Moyen Âge, Actes du colloque international tenu à Saint-Lizier du $1^{\text {er }}$ juin au 4 juin 1995, Poitiers, CESCM: 121-137

REY, Raymond, 1945. “Les peintures de l'ancien palais abbatial de Moissac”, Revue archéologique, XXIII:116-121

Rosé, Isabelle, 2001. “Commutatio. Le vocabulaire de 1'échange chrétien du haut Moyen Âge”, Les élites et la richesse au haut Moyen Âge, J.-P. Devroey, L. Feller, R., Le Jan (eds.), Turnhout, Brepols: 113-138

Skubiszewski, Piotr, 2005. “Maiestas Domini et liturgie", Cinquante années d'histoire médiévale. Á la confluence de nos disciplines, Cl. Arrignon, M.-H. Debiès, Cl. Galderisi, É. Palazzo (eds.), Turnhout, Brepols: 309-408

TOUBERT, Hélène, 1990. Un art dirigé, Réforme grégorienne et iconographie, Paris, Cerf

Whitehend, Christiana, 2003. Castles of the Mind, A Study of Medieval Architectural Allegory, Cardiff, University of Wales Press 
Fig. 1
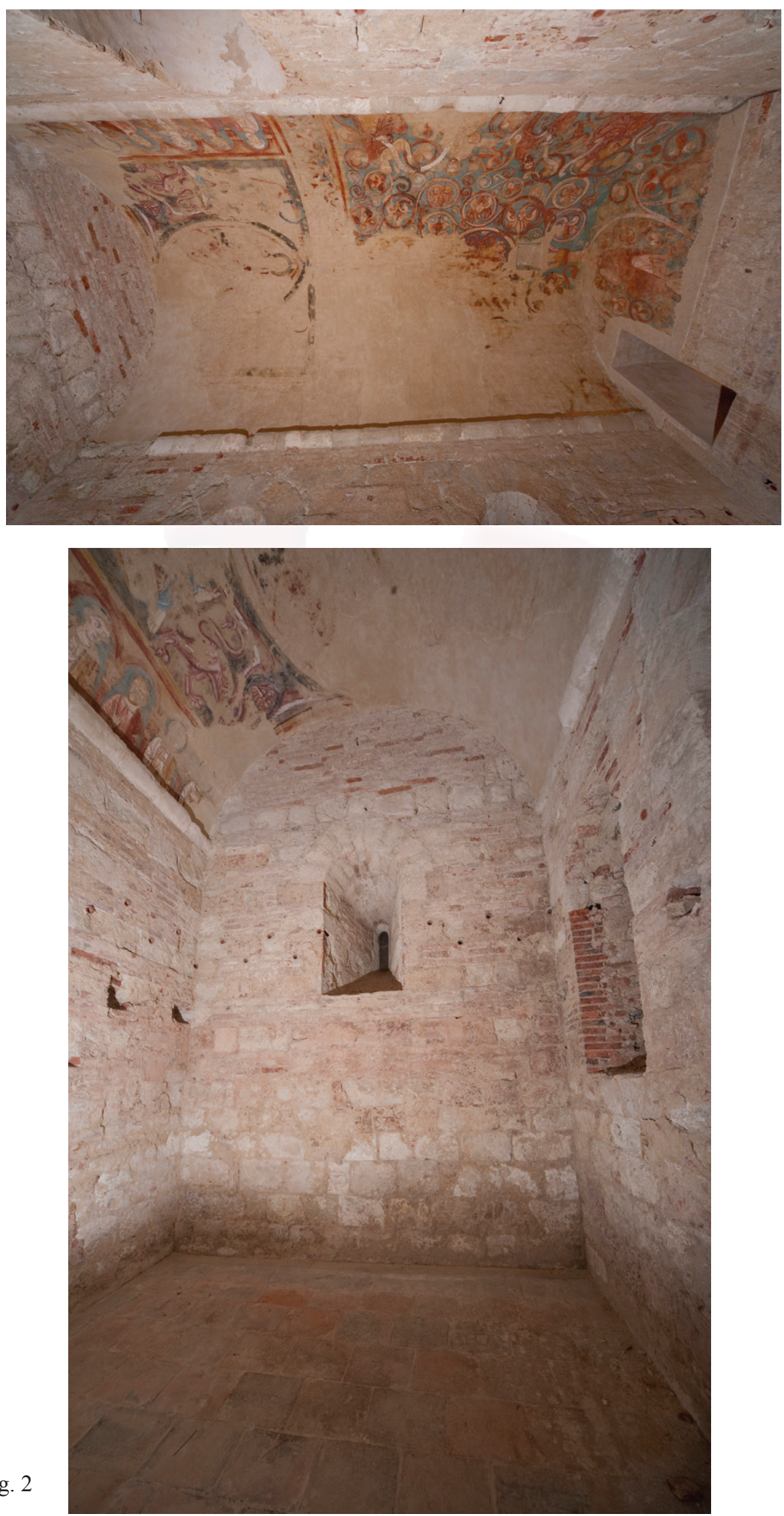

Fig. 2 


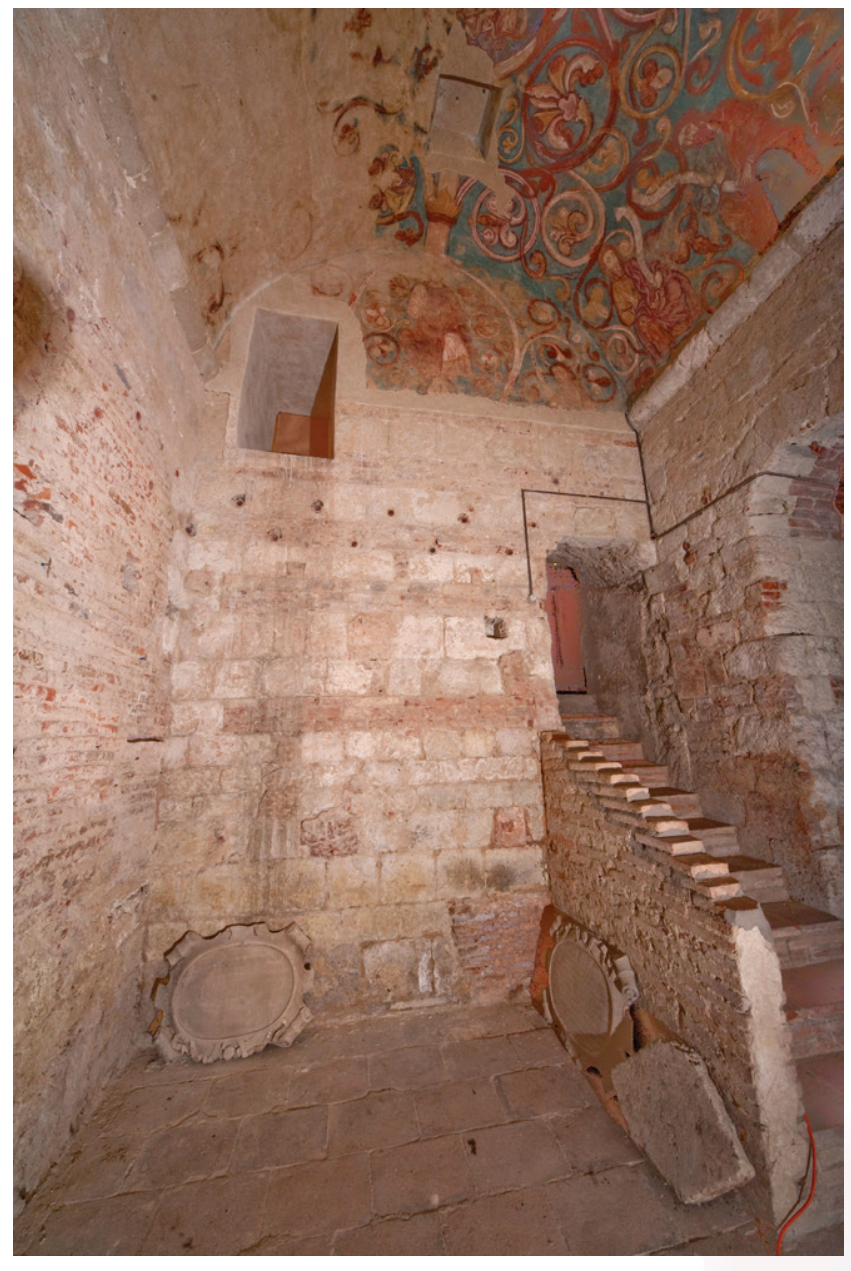

Fig. 3

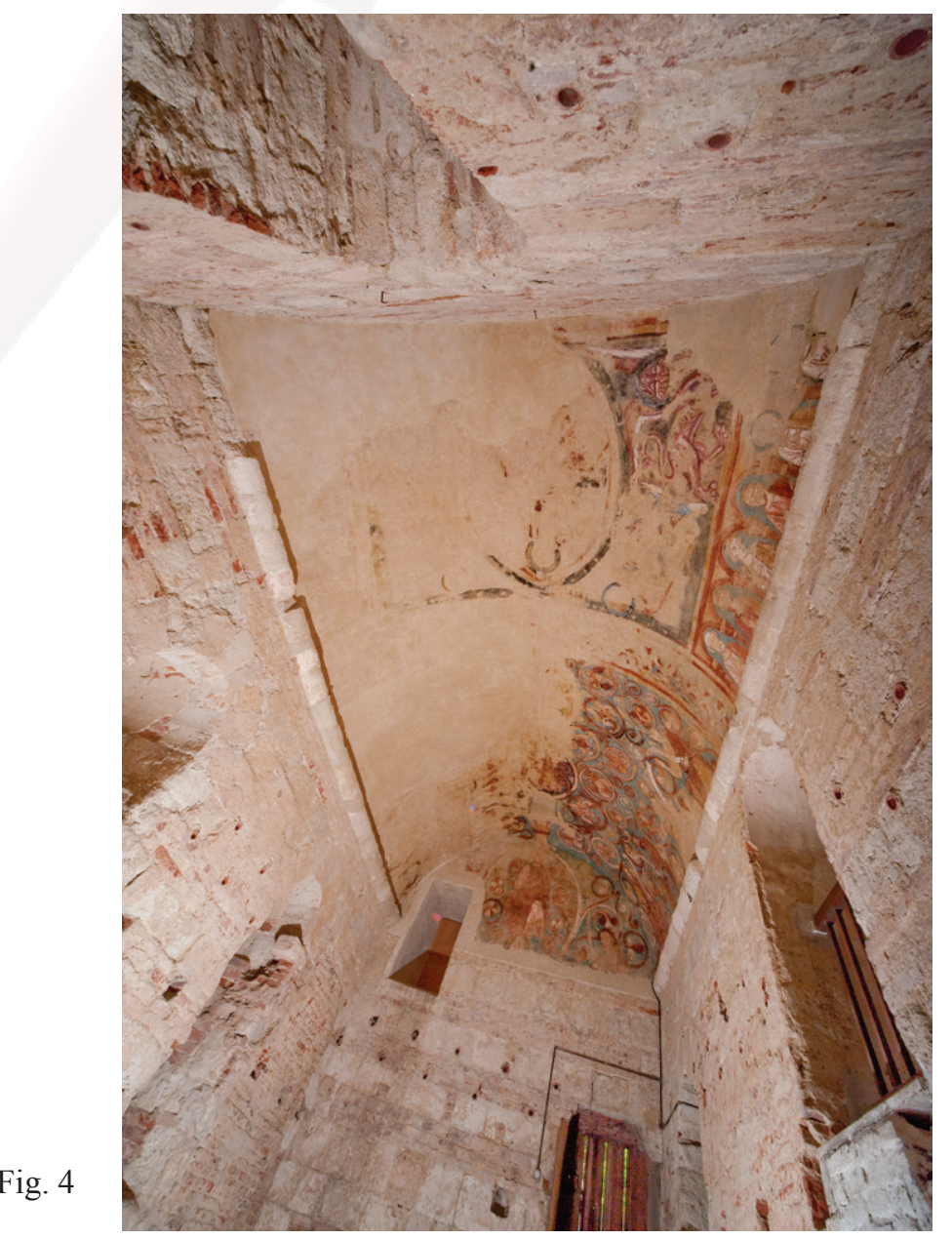




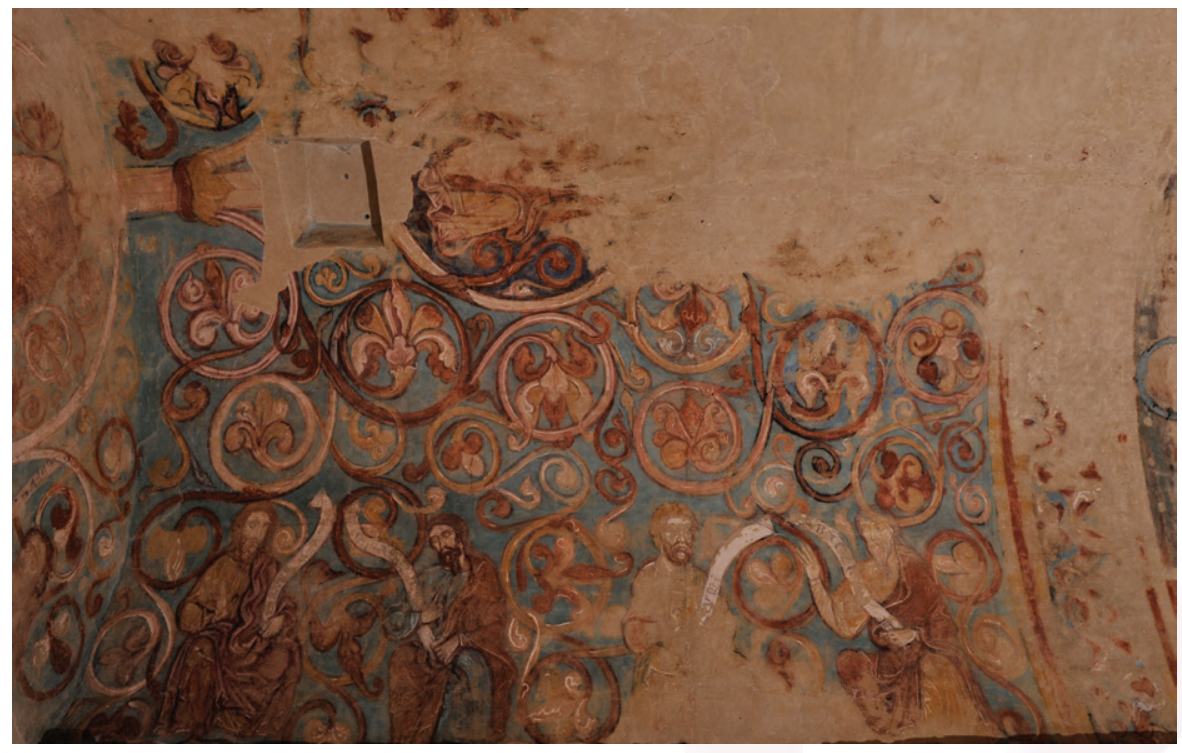

Fig. 5

Fig. 6

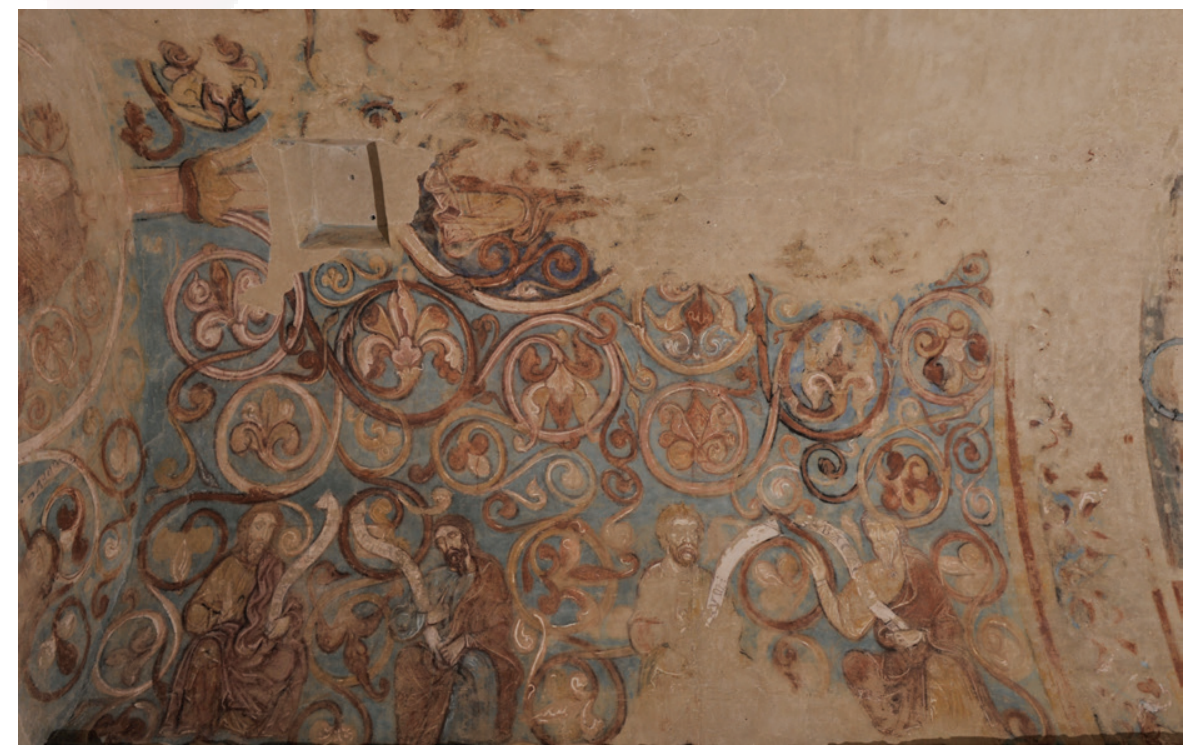




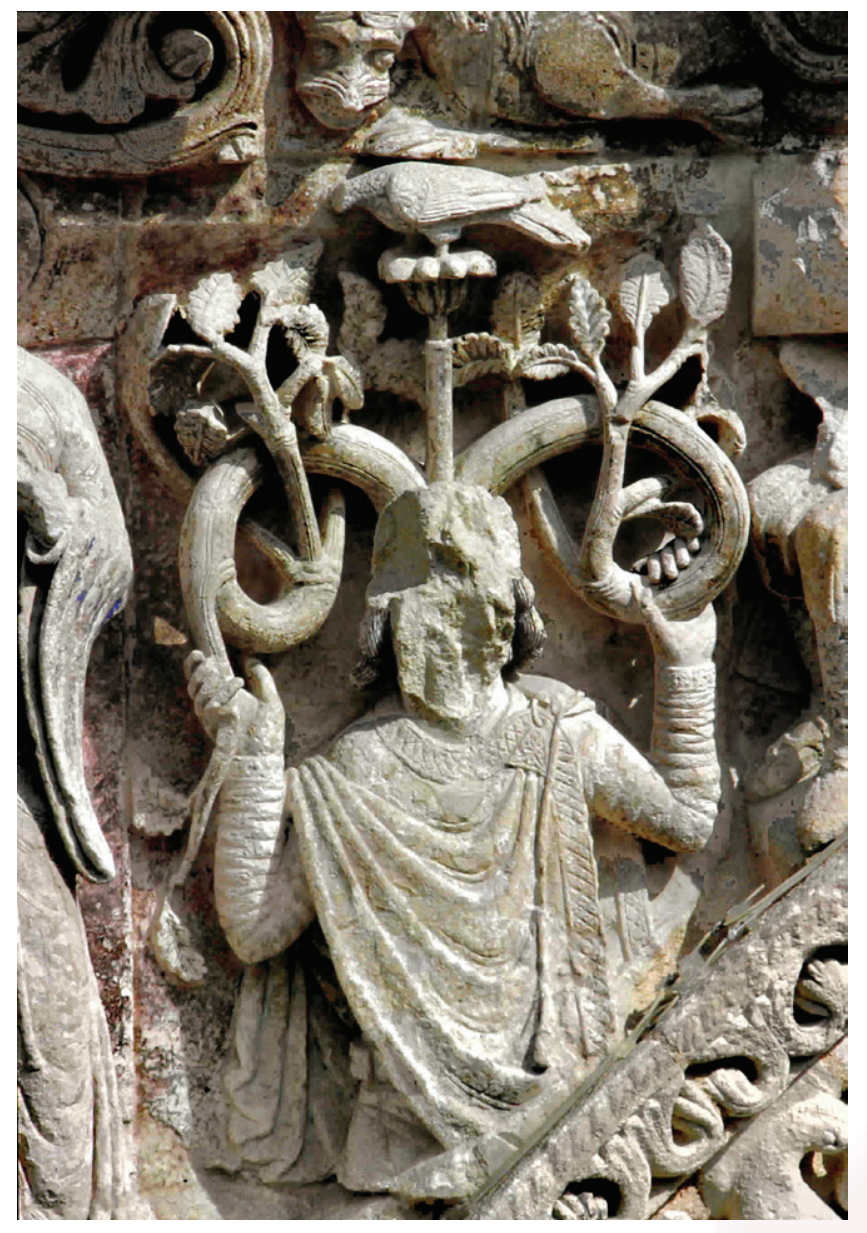

Fig. 7

Fig. 8
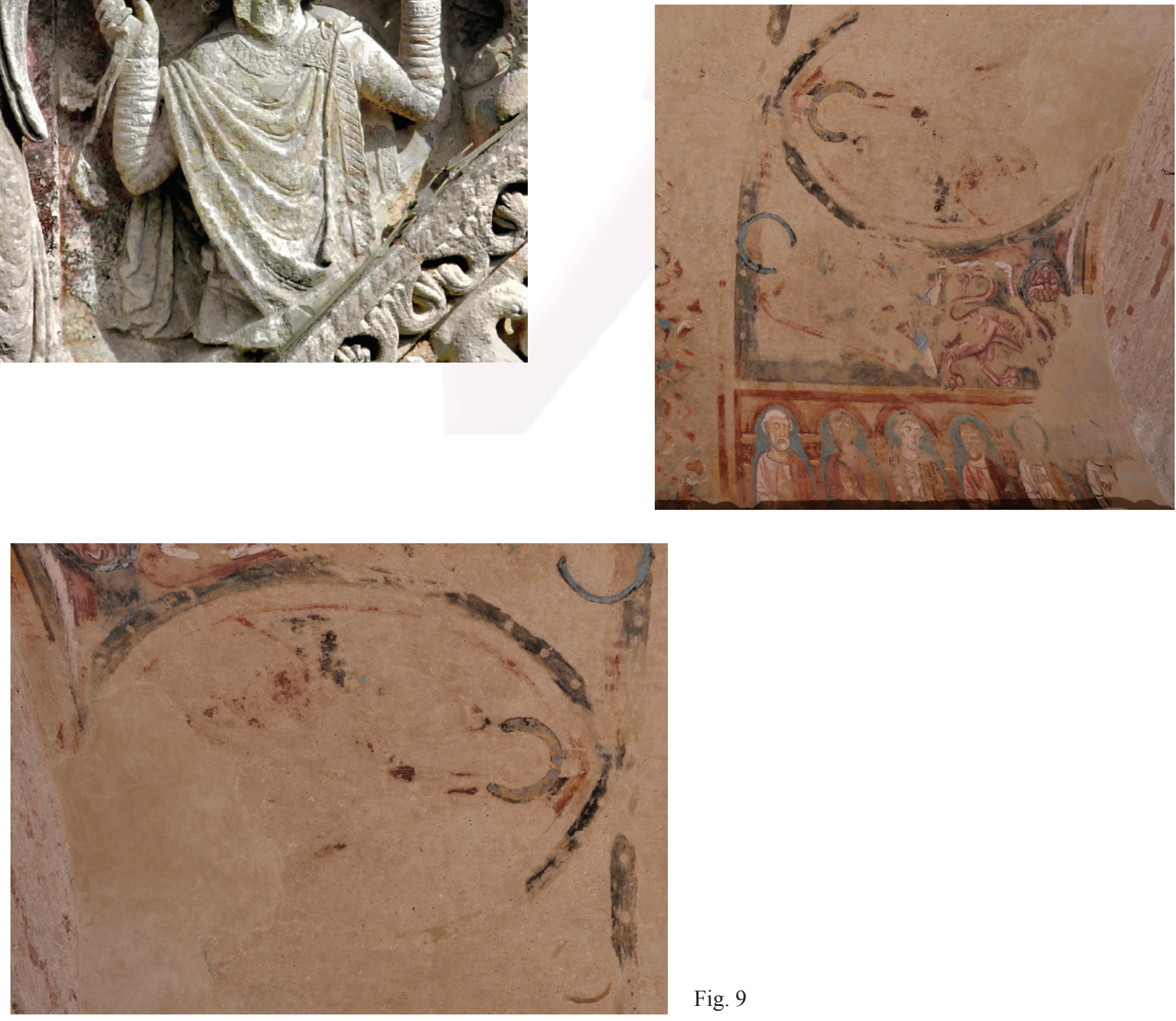

Fig. 9 